\title{
Growth of the Chilean plants Haplopappus macrocephalus and Selliera radicans on an extensive modular green roof system under three irrigation regimes
}

\author{
Crecimiento de las plantas chilenas Haplopappus macrocephalus y Selliera \\ radicans en sistema modular de techo verde bajo tres regímenes de riego
}

\author{
Flavia Schiappacasse ${ }^{1}$, Eugenio Rodríguez ${ }^{1}$, Panayiotis A. Nektarios ${ }^{2}$, \\ Karen M. Gaete ${ }^{1}$, Lydia D. Maturana ${ }^{1}$
}

\begin{abstract}
There is an increasing trend in Chile to establish green roofs in urban areas using native plants in order to reintroduce the lost flora in the cities. Most Chilean cities are located in the central zone, where mediterranean climate predominates with minimal rainfall during the hot summer period. Thus green roofs require an irrigation system to provide sustainable plant growth. The present study evaluated the effect of different irrigation regimes (two irrigations per day; one irrigation per day and four irrigations per week) on the growth of two native species, Haplopappus macrocephalus and Selliera radicans, planted in Talca. The study utilized green roof modules made with recycled and shredded ethylene vinyl acetate (EVA), with a drainage system capable of retaining a portion of the runoff water. Plant survival was 100\% in H. macrocephalus and $96 \%$ in S. radicans. Plant growth was similar for all irrigation treatments as well as flowering for both species. The only differences observed were in dry matter accumulation for $H$. macrocephalus, where irrigation once or twice a day increased aerial dry weight compared to irrigation four times a week. In contrast, root dry matter accumulation was similar for all three irrigation treatments. Both species would be suitable for Talca green roof plantings; irrigation can be applied four times per week in order to save water resources without endangering plant growth or flowering.
\end{abstract}

Key words: dry weight, mediterranean climate, plant survival, Chilean native plants.

\section{RESUMEN}

Existe una tendencia creciente en Chile a establecer techos verdes utilizando especies nativas, de modo de reintroducir la flora perdida en la ciudad. La mayor parte de las ciudades chilenas están ubicadas en la zona central, donde predomina el clima mediterráneo, con escasa pluviometría durante el período estival. Por este motivo, los techos verdes requieren un sistema de riego para proveer un crecimiento sostenible de las plantas. En el presente estudio se evaluó el efecto de diferentes regímenes de riego (dos riegos diarios, un riego diario y cuatro riegos semanales) sobre el crecimiento de dos especies nativas, Haplopappus macrocephalus y Selliera radicans, establecidas en Talca. En el estudio se utilizaron módulos de techos verdes compuestos por etilenvinilacetato (EVA) reciclado y trozado, con un sistema de drenaje capaz de retener una porción del exceso de agua lluvia. La sobrevivencia de las plantas fue de $100 \%$ en $\mathrm{H}$. macrocephalus y $96 \%$ en S. radicans. En las dos especies, tanto el crecimiento de las plantas como la floración fueron similares para todos los tratamientos de riego. Las únicas diferencias observadas fueron con respecto a la materia seca acumulada en $\mathrm{H}$. macrocephalus, donde el riego diario o dos veces al día aumentó el peso seco aéreo, en comparación con el riego cuatro veces a la semana. En contraste, la acumulación de materia seca radical fue similar en los tres tratamientos de riego. Ambas especies serían apropiadas para plantar en techos verdes en Talca, pudiendo regar cuatro veces a la semana de modo de ahorrar agua sin comprometer negativamente el crecimiento y floración de las plantas.

Palabras clave: peso seco, clima mediterráneo, sobrevivencia de plantas, plantas nativas de Chile.

1 Facultad de Ciencias Agrarias, Universidad de Talca, Talca, Chile.

2 Laboratory of Floriculture and Landscape Architecture, Department of Crop Science, Agricultural University of Athens

* Corresponding author: fschiap@utalca.cl

Fecha de Recepción: 15 Enero, 2017.

Fecha de Aceptación: 20 Agosto, 2017. 


\section{Introduction}

Green roofs provide multiple environmental and ecological benefits in urban areas, such as their ability to improve storm water management by storing rainfall water and then slowly releasing runoff (Getter et al., 2007), mitigate urban heat island effect (Takebayashi and Moriyama, 2007), improve building energy conservation due to lower cooling needs (Kotsiris et al., 2012a; Santamouris et al., 2007), reduce sound nuisance (Van Renterghem and Botteldooren, 2008) and ameliorate urban air by trapping and removing air pollutants (Yang et al., 2008). Further advantages include green roof contribution to carbon sequestration (Getter et al., 2009), increased longevity of roof membranes (Kosareo and Ries, 2007), increased urban biodiversity of flora and fauna and improvement of urban aesthetics and amenity.

Many of these benefits are expected to be valuable to the urban centers of Chile's central zone, especially as a means of reducing the increased air pollution and as a strategy for urban runoff reduction. Lack of professional knowledge and regulations in conjunction with minimal governmental incentives and increased green roof installation costs have hindered their wide use in urban Chilean landscapes. Despite the abovementioned hurdles, green roof utilization has increased recently and a technical group has been founded under the Chilean Building Chamber in order to perform research and develop local guidelines for green roofing. However, these advantages are expected to occur only if green roofing is implemented in large urban areas (Nektarios et al., 2011, 2014, 2015; Kokkinou et al., 2016; Ntoulas et al., 2015).

Green roofs are multi-layered constructions, which are classified as extensive, intensive or semiintensive (FLL, 2008). The classification of the three green roof types is based on both the substrate depth, the plant types capable of providing sustainable growth on the roof and the required maintenance level. Intensive green roof types have deep substrate depths capable of hosting various plant types ranging from turfgrasses to large trees. Their construction cost is high, their maintenance is intensive and they exert significant load on building frameworks. Thus their use is aimed towards the new buildings that have been designed to withstand the additional loading. In contrast, extensive green roof systems have shallow substrate depths that can host a limited number of plant species having low growth habits. Their construction cost is reduced compared to the intensive types, and the maintenance requirements and the load exerted to the buildings are minimum.

Taking into consideration that the largest proportion of existing buildings in urban city centers are occupied by old buildings with minimal capacity to withstand additional loads, it is obvious that extensive green roofing seems the most appropriate approach to reintroduce the lost flora in the cities. In most cases extensive green roofs are planted with succulent species mainly from the genus Sedum (Durhman et al., 2007; Snodgrass and Snodgrass, 2006; Nektarios et al., 2015) which is also the case for Chilean extensive green roofs. However, there is a significant worldwide trend to utilize native species that are better adapted to the local conditions and pests, provide better aesthetics and avoid the problems of monocultures (Benvenuti and Bacci, 2010; Nektarios et al., 2012, 2015; Kokkinou et al., 2016; Kotsiris et al., 2012b). The task is challenging due to minimal substrate depth of the extensive green roof systems, exacerbated by the harsh environmental conditions that prevail on the roofs of buildings and the need for minimal maintenance requirements. Therefore Kotsiris et al. (2012b) introduced the adaptive green roof concept, which utilizes the minimal substrate depth of extensive green roof systems combined with prudent resource inputs such as irrigation. Thus adaptive green roof systems have minimal load while at the same time the plant selection palette is greatly increased.

Efforts to use Chilean native plants in urban landscaping and green roof systems have already been recorded in Chile (Olate et al., 2013), boosted by the need to acquaint LEED certification in corporative buildings. The present study aims to evaluate growth of two native species on green roof systems under different irrigation regimes. The selected species were Haplopappus macrocephalus and Selliera radicans (Figure 1); these are ground covers that grow best under full sun. H. macrocephalus is endemic to Chile, belongs to the family Asteraceae and is found naturally and abundantly. It has rosette-type leathery leaves and short stems bearing adventitious roots when in contact with the soil; the upright top bears yellow to orange flowers in solitary and erect heads. It has low water requirements (Riedemann and Aldunate, 2014). The second plant species, $S$. radicans, is native to Australia, New Zealand and Chile, and grows in wetlands usually associated with 


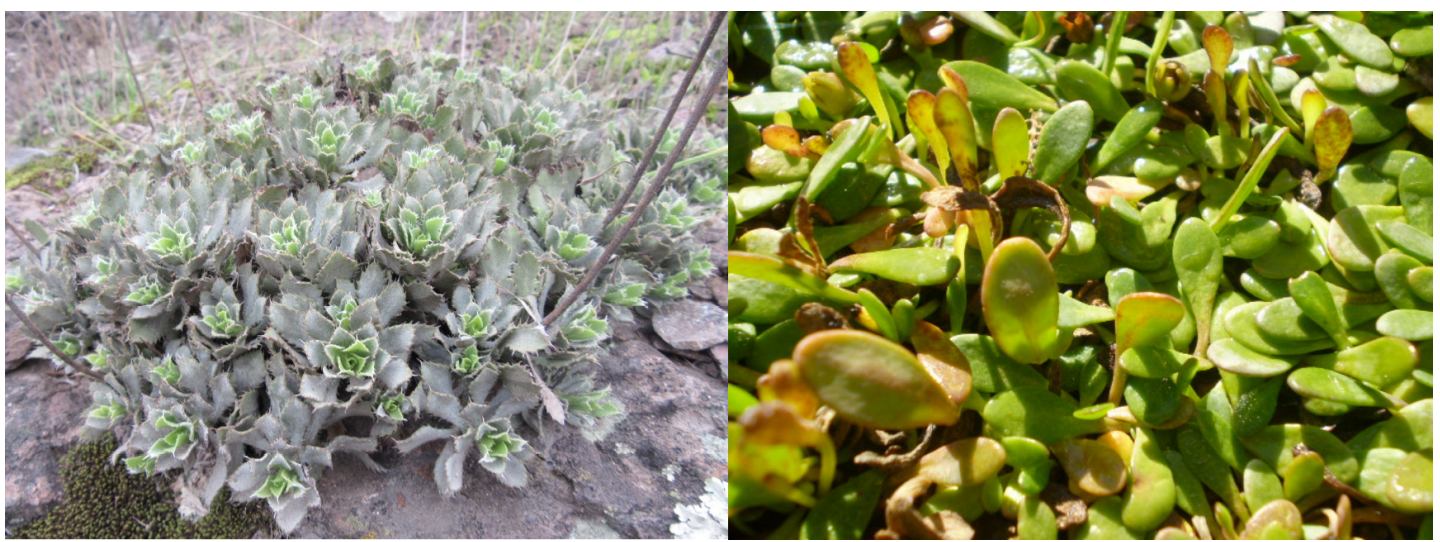

Figure 1. Haplopappus macrocephalus (A) and Selliera radicans (B) plants in their natural habitats.

coastal areas. Its water requirements are normal to high. The plant produces stolons that bear fibrous roots in the nodes and leaves that are obloanceolate to obovate, succulent, light green and shiny. Flowers are small, solitary, zygomorphic, with 5 white petals with reddish lines in the upper part. In contrast to several native species that have a rest period with unacceptable aesthetics (Getter and Rowe, 2008), both $H$. macrocephalus and $S$. radicans have yearround growth and aesthetical contribution if moisture is available.

\section{Materials and Methods}

\section{Experimental setup}

The study was conducted from December 2013 to April 2014 at the University of Talca (35 24'S, $\left.71^{\circ} 38^{\prime} \mathrm{W}\right)$. The specific time period was selected since it is characterized by extended dry periods with high temperatures. Ambient maximum, minimum and average air temperature and precipitation were recorded by the Weather Station at the University of Talca, located $100 \mathrm{~m}$ from the experimental site (Figure 1).

The study used green roof modules imported from Brazil (Ecotelhados, Rua Erechim 330, Bairro Nonoai, Loja Porto Alegre) made of recycled and shredded EVA (ethylene vinyl acetate), agglomerated with Portland CP-IV cement and with addition of ashes (Figure 2). Each light grey module weighs $4.8 \mathrm{~kg}$. The exterior dimensions are $35 \times 70 \times 7 \mathrm{~cm}$, and it contains 8 rectangular cells of $12 \times 12 \mathrm{~cm}$ and $4.5 \mathrm{~cm}$ depth. The cells were filled with a substrate mixture that contained the following locally available constituents in volumetric proportions:

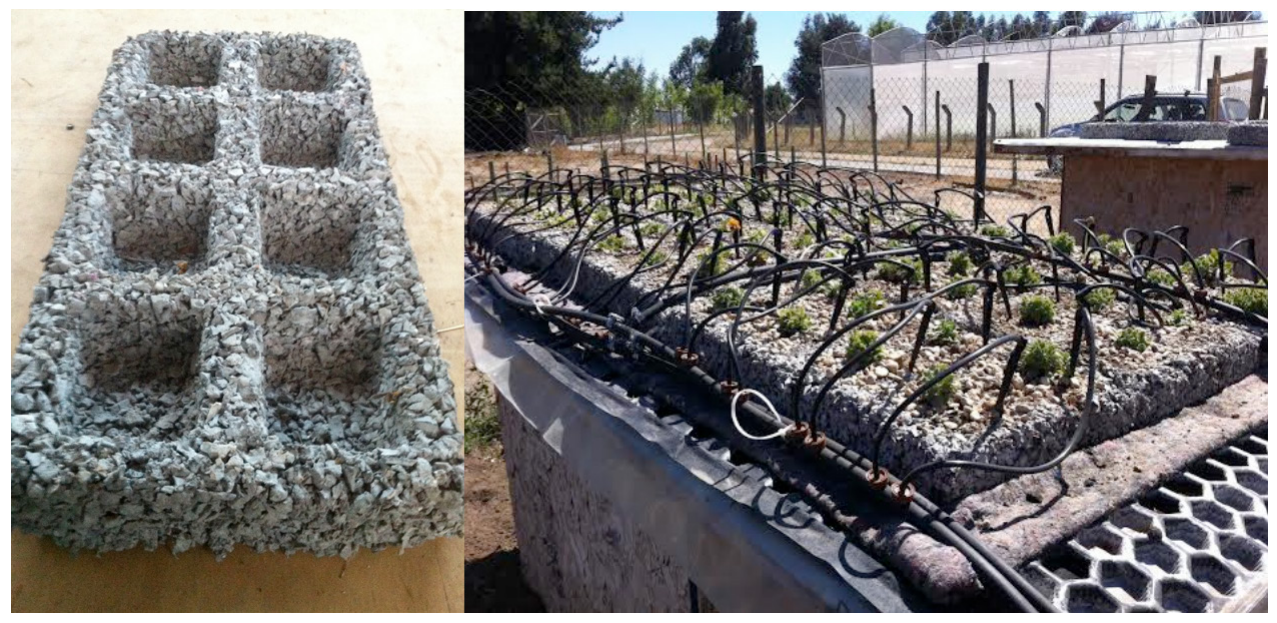

Figure 2. Green roof module of 'Ecotelhados' (A) and installed modules at the experimental site (B). 
$37 \%$ pumice collected in the Andes with a particle distribution of 1-6 mm; $15 \%$ clinoptinolite zeolite (1.5-8 $\mathrm{mm}$ ) from the Maule Region ('Zeolita del Maule', Quinamávida s/n, comuna de Colbún, Linares); $8 \%$ shredded fired clay (1-2 $\mathrm{mm}$ ) and $40 \%$ compost made from nut shells of Gevuina avellana that were composted for two years (Millantú, Talca). The compost and substrate mix chemical composition were analyzed at the Soil and Crops Center of the University of Talca (Table 1). The particle size distribution (Figure 2) and the water potential curve (Figure 3) were determined by the Laboratory of Soil and Plants of the Universidad de Concepción, Concepción, Chile.

Table 1. Chemical characteristics of the compost made from composted nut shells of Gevuina avellana (Millantú, Talca).

\begin{tabular}{lc}
\hline $\mathrm{pH}$ & 4.26 \\
\hline Electrical conductivity $\left(\mathrm{dS} \mathrm{m}^{-1}\right)$ & 1.01 \\
Organic matter (\%, weight basis) & 49.57 \\
Total C (\%) & 27.54 \\
$\mathrm{C} / \mathrm{N}$ relationship & 42 \\
$\mathrm{~N}(\%)$ & 0.66 \\
$\mathrm{P}(\%)$ & 0.34 \\
$\mathrm{~K}(\%)$ & 0.54 \\
$\mathrm{Mg}(\%)$ & 0.17 \\
$\mathrm{Ca}(\%)$ & 0.17 \\
$\mathrm{Na}(\%)$ & 0.03 \\
$\mathrm{Fe}\left(\mathrm{mg} \mathrm{kg}^{-1}\right)$ & 17.817 \\
$\mathrm{Mn}\left(\mathrm{mg} \mathrm{kg}^{-1}\right)$ & 607 \\
$\mathrm{Cu}\left(\mathrm{mg} \mathrm{kg}^{-1}\right)$ & 90 \\
$\mathrm{Zn}\left(\mathrm{mg} \mathrm{kg} \mathrm{k}^{-1}\right)$ & 38
\end{tabular}

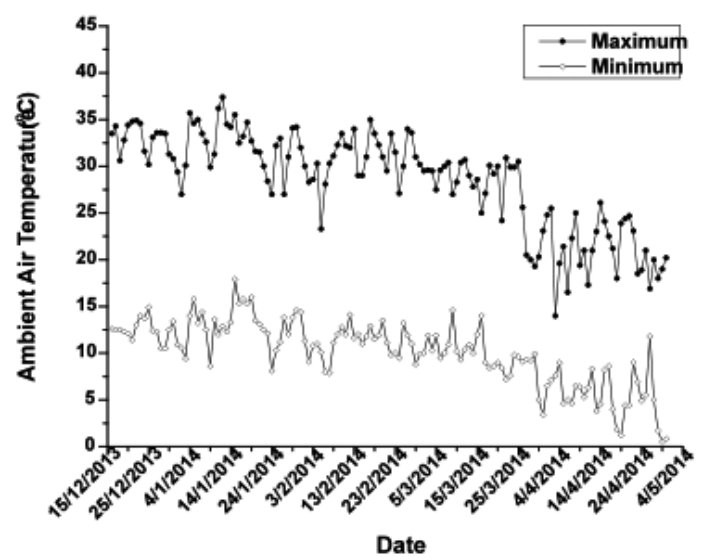

Figure 3. Maximum and minimum daily air temperatures $\left({ }^{\circ} \mathrm{C}\right)$ throughout the study that lasted from 18 Dec. 2013 to $30 \mathrm{Apr}$. 2014. Source: www.citrautalca.cl

\section{Plant material}

Plants of H. macrocephalus were collected on 23 Aug. 2013 as stems with adventitious roots from a natural habitat in the vicinity of Talca, where it grew abundantly. The stems were planted in trays filled with sawdust before they were transplanted to the modules on 30 Aug. 2013. A single plant was planted in each module cell. The modules were kept under an unheated polyethylene greenhouse from 30 Aug. to 23 Oct. 2013. The $S$. radicans mother plants were already available in trays, started from stolons collected in the wild the previous year. Rooted stolons with 2-3 nodes were excised from the mother plants and planted directly in the module cells, one plant section per cell. Nine modules were prepared for each species, totaling 72 plants per species. One module (with 8 plants) constituted one replication, and there were 3 replications per treatment in each species.

The planted modules were installed on 23 Oct. 2013 on two separate wooden structures $(126 \times 102 \mathrm{~cm}$ and more than $1 \mathrm{~m}$ high) that simulated roofs, covered with a piece of undulated zinc sheet with $9 \%$ inclination. Both the roof and the wooden structures had a northern orientation. The zinc sheet was covered with a black polyethylene film $0.25 \mathrm{~mm}$ thick, and over it was placed a layer of rigid polyethylene (provided by 'Ecotelhados'). This rigid polyethylene had round alveoli of $6 \mathrm{~cm}$ in diameter with the capacity to retain water. Finally, on top of the rigid polyethylene a wool felt fabric layer (80-95\% wool, Plasmo, Plásticos Morales, Santiago, Chile) was placed; it had a thickness of $0.5 \mathrm{~cm}$ and a water retention capacity of $2.3 \mathrm{~L} \mathrm{~m}^{-2}$. The modules were placed on top of the fabric (Figure 2). The roof of one structure was covered with modules planted with $H$. macrocephalus plants and the other was covered with $S$. radicans plants.

\section{Irrigation regimes}

Three irrigation treatments were applied with different frequency of application: a) two irrigations per day $\left[\mathrm{D}_{2}\right]$, b) one irrigation per day $\left[\mathrm{D}_{1}\right]$, and c) 4 irrigations per week (Monday, Wednesday, Friday and Sunday) [W]. A drip irrigation system was installed, using drippers, a microtube and a pin to secure the microtube end in the substrate. Replications were distributed randomly within the plots. An irrigation programmer (Hunter, X-core) 
was used. The irrigation time was determined by measuring the water needed to saturate one cell $(300 \mathrm{~mL})$, which was determined equal to $7.05 \mathrm{~min}$. Therefore each irrigation cycle was scheduled to last 10 min per irrigation cycle. Irrigation was applied at 8:00 for the single day irrigation treatments $\left[D_{1}\right.$ and $\mathrm{W}]$ and at 8:00 and 16:00 for the $\mathrm{D}_{2}$ treatment.

\section{Measurements}

At the end of the growing period (April), H. macrocephalus growth was determined based on the Growth Index $[(\mathrm{L}+\mathrm{W}+\mathrm{H}) / 3]$, where $\mathrm{L}$ is plant length at the widest part of the foliage $(\mathrm{cm})$, $\mathrm{W}$ is the maximum plant foliage width measured perpendicularly to the length measurement $(\mathrm{cm})$, and $\mathrm{H}$ is the plant height without considering the flowering stems. The growth of $S$. radicans was determined by multiplying length by width as described above without considering height, which was constant due to its prostrate growth habit. In addition the number of branches was recorded for H. macrocephalus plants.

The number of flowers was determined from the moment of module planting on the green roof system. On 30 Apr. 2014 plants were collected from the modules, washed completely to remove substrate particles and placed in a drying oven at $60^{\circ} \mathrm{C}$ for 6 days to determine their dry matter.

\section{Statistical analyses}

Each species was placed in a separate structure and thus species data were analyzed separately. For each of the two species, three irrigation treatments with three replications were utilized. A single module planted with 8 plants was considered as one replication. The replications were distributed randomly. The treatments were the three irrigation regimes. The data was analyzed with analysis of variance, and the HSD test was used to compare means, using the Statgraphics Centurion XVI.II software.

\section{Results and Discussion}

During the experiment period (December 2013 to April 2014) the minimum observed temperature was $-0.6{ }^{\circ} \mathrm{C}$ (April) and the maximum was $37.1^{\circ} \mathrm{C}$ (January). During December and January most maximum air temperatures exceeded $30^{\circ} \mathrm{C}$ (Figure 3). Rainfall was 0, 0.9, 0.2, 12.3 and $14 \mathrm{~mm}$, respectively for each month from December to April, and the air humidity averages were lowest in December (54\%) and January (54.8\%), and peaked in April (77\%) (www.citrautalca.cl).

The particle size distribution of the mineral part of the selected substrate was determined with the existing guidelines (FLL, 2008) for green roof growing substrates (Figure 4). It is

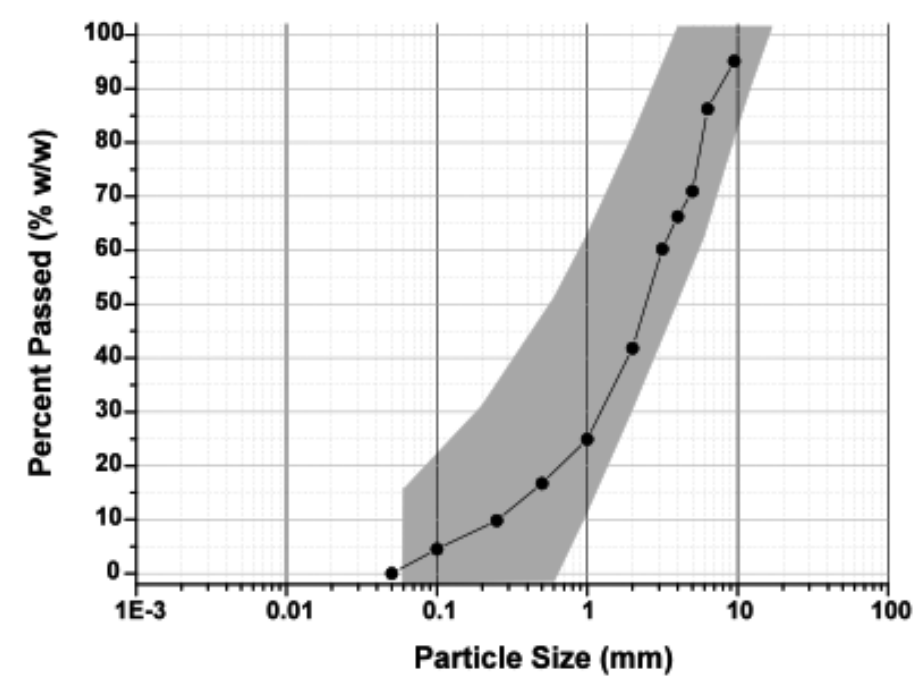

Figure 4. Particle size distribution of utilized green roof substrate composed of volumetric proportions of pumice $(37 \%)$, zeolite $(15 \%)$, shredded fired clay $(8 \%)$ and compost $(40 \%)$. The light grey area represents the particle size distribution proposed by the Forschungsgesellschaft Landschaftsentwicklung Landschaftsbau (2008) guidelines for extensive green roofs. Values are the means of three replications. 
of interest that all materials that constituted the green roof substrate were locally available, thus reducing its environmental footprint as well as its cost. However, it was decided that the organic matter of the substrate mix should exceed the recommended rate proportion, due to its increased $\mathrm{C} / \mathrm{N}$ ratio (42) and its low organic matter compared to other composted materials (Table 1). Increased organic matter participation is usually avoided due to the problem of its decomposition that leads to substrate depth reduction. However, this problem is eliminated if the composted material has a low decomposition rate.

The water holding capacity of the substrate was adequate but not excessive (Figure 5). The coarse texture of the selected substrate (Figure 4) resulted in an increased porosity of $71.4 \% \mathrm{v} / \mathrm{v}$ that did not permit excessive water, which reached $30.5 \%$ at saturation. The substrate drained quickly, holding $21 \% \mathrm{v} / \mathrm{v}$ water at a $1 \mathrm{~atm}$ tension. Even at a tension of $15 \mathrm{~atm}$ the water holding capacity of the substrate was $14 \% \mathrm{v} / \mathrm{v}$, which is considered low but adequate for xerophytes and succulent plants (Nektarios et al., 2015).

Based on the particle size distribution and the moisture retention capacity of the substrate, the three irrigation treatments would be expected to have a significant impact on plant growth. However, this was not the case for either of the two species under evaluation. More specifically, the growth of H. macrocephalus was similar among the three irrigation treatments and only the percent increase of the growth index was promoted in irrigation treatments with a single or a double irrigation event every day (Table 2). Similarly, S. radicans exhibited a similar growth index in the three irrigation treatments (Table 3).

Several researchers have reported that succulent plants that have Crassulean Acid Metabolism (CAM) seem to be the most appropriate selections for establishing extensive green roof systems due to their minimal water requirements and shallow root growth habit (Monterusso et al., 2005; Snodgrass and Snodgrass, 2006). Similarly, Nektarios et al. (2015) reported that the native species Sedum sediforme was able to survive in shallow green roof conditions under the Mediterranean summer without any water application. H. macrocephalus is not considered a succulent plant, while $S$. radicans is a succulent species that certainly would not survive in Talca without irrigation, and there is no evidence to indicate that its metabolism is CAM. H. macrocephalus showed a long and strong root system in this study. Despite these points, both species had good performance on green roofs during the months of this study, but their performance after more than one season is unknown.

The H. macrocephalus plants flowered from their establishment until the end of the study, having

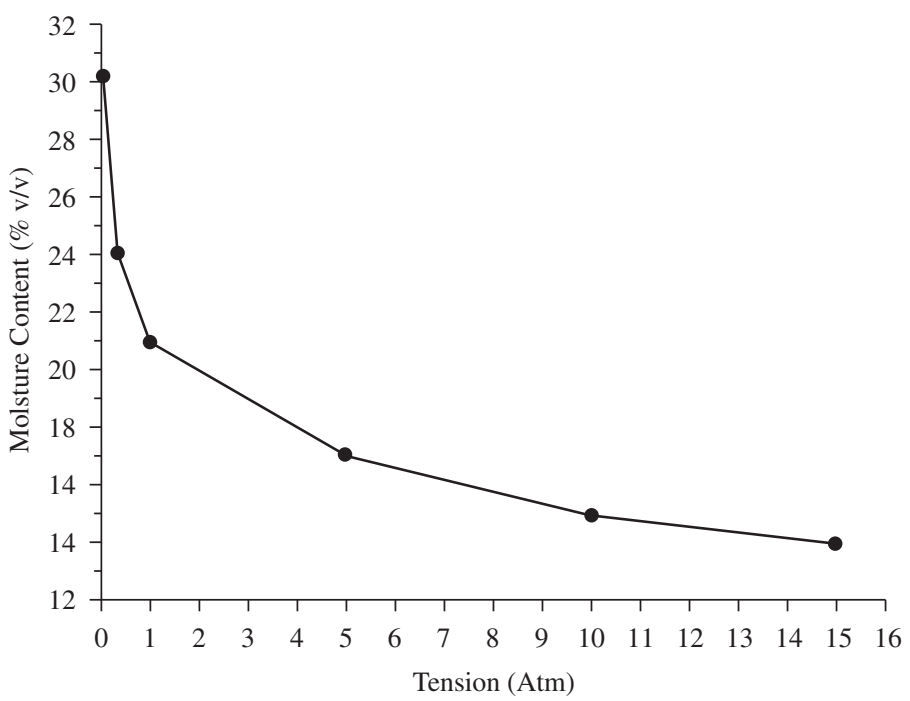

Figure 5. Moisture potential curve for utilized green roof substrate composed of pumice (37\%), zeolite (15\%), shredded fired clay (8\%) and compost (40\%). Values are the means of three replications. 
Table 2. Plant growth measured as Growth Index (cm), from December 2013 to April 2014 for Haplopappus macrocephalus plants under different irrigation regimes (two irrigations per day $\left[\mathrm{D}_{2}\right]$; one irrigation per day $\left[\mathrm{D}_{1}\right]$; four irrigations per week $[\mathrm{W}]$ ) in Talca, Chile. Values are the means of 24 plants.

\begin{tabular}{|c|c|c|c|}
\hline \multirow[t]{2}{*}{ Irrigation regime } & $\begin{array}{l}\text { Initial Growth Index } \\
\text { (16 Dec. 2013) } \\
\end{array}$ & $\begin{array}{l}\text { Final Growth Index } \\
\text { (16 Apr. 2014) }\end{array}$ & $\begin{array}{l}\text { Percent increase } \\
\text { in Growth Index }\end{array}$ \\
\hline & $\mathrm{cm}$ & $\mathrm{cm}$ & $\%$ \\
\hline Twice per day $\left[\mathrm{D}_{2}\right]$ & 6.0 & 7.9 & $31.7 \mathrm{a}$ \\
\hline Once per day $\left[\mathrm{D}_{1}\right]$ & 6.3 & 8.0 & $27.0 \mathrm{a}$ \\
\hline Four times per week [W] & 5.7 & 6.7 & $17.5 \mathrm{~b}$ \\
\hline Significance $\dagger$ & NS & NS & $*$ \\
\hline
\end{tabular}

$\dagger \mathrm{NS}$, *, not significant and significant at $\mathrm{P}<0.05$ using the HSD test, respectively. Values followed by the same letter within a column are not statistically different.

Table 3. Plant cover measured as Growth Index (cm), from December 2013 to April 2014 for Selliera radicans plants under different irrigation regimes (two irrigations per day $\left[\mathrm{D}_{2}\right]$; one irrigation per day $\left[D_{1}\right]$; four irrigations per week $\left.[W]\right)$ in Talca, Chile. Values are the means of 24 plants.

\begin{tabular}{|c|c|c|c|}
\hline \multirow[t]{2}{*}{ Irrigation regime } & $\begin{array}{l}\text { Initial Growth Index } \\
\text { (16 Dec. 2013) }\end{array}$ & $\begin{array}{l}\text { Final Growth Index } \\
\text { (16 Apr. 2014) }\end{array}$ & $\begin{array}{l}\text { Percent increase } \\
\text { in Growth Index }\end{array}$ \\
\hline & $\mathrm{cm}$ & $\mathrm{cm}$ & $\%$ \\
\hline Twice per day [D2] & 71 & 164.3 & $131.4 \mathrm{a}$ \\
\hline Once per day [D1] & 74.3 & 118 & $58.8 \mathrm{~b}$ \\
\hline Four times per week [W] & 75 & 123.7 & $64.9 \mathrm{~b}$ \\
\hline Significance $\dagger$ & NS & NS & $*$ \\
\hline
\end{tabular}

$\dagger \mathrm{NS}$, *, not significant and significant at $\mathrm{P}<0.05$ using the HSD test, respectively. Values followed by the same letter within a column are not statistically different.

up to 10 flowers per plant; no differences were found among treatments. The $S$. radicans plants started flowering in November, 2013, before the initiation of the irrigation study, while the modules were already installed on the roofs. S. radicans exhibited a peak in its flowering in December and flowered until February, with very few flowers in March. The total flower count per S. radicans plant was 1.75 when the plants were irrigated twice a day [D2], 1.1 when plants were irrigated once a day [D1] and 1.7 when plants were irrigated 4 times per week [W]. There was no significant difference among the three irrigation treatments in either of the two species tested.

In contrast to the growth index measurements, the aerial and root dry matter showed differences in H. macrocephalus plants between the three irrigation treatments. More specifically, treatments that applied water once or twice a day produced more dry matter in the aerial part but not for the root system (Table 4). Such differences were not detected for $S$. radicans, either for top or for root growth.

\section{Conclusions}

Both H. macrocephalus and S. radicans showed sufficient growth and similar flowering in all three irrigation treatments. Based on the macroscopic observations and growth monitoring, both native plant species are appropriate for green roof plantings in the Talca region. Due to the fact that irrigation treatments did not provide significant differences in growth and flowering, it is suggested that infrequent irrigation applications (four per week) are adequate for $H$. macrocephalus and S. radicans to sustain growth and flowering. Due to their interesting features, it is necessary to conduct further research in order to determine the drought tolerance of these plants under the shallow substrate conditions of the green roofs for more than one season.

\section{Acknowledgments}

Materials for this project were provided by Catalina Barros, manager of Agricola Vitaflor. 
Table 4. Aerial and root dry matter (g) of Haplopappus macrocephalus and Selliera radicans plants grown under different irrigation regimes (two irrigations per day $\left[\mathrm{D}_{2}\right]$; one irrigation per day $\left[\mathrm{D}_{1}\right]$; four irrigations per week $\left.[\mathrm{W}]\right)$ in Talca, Chile. Data correspond to the end of the study (30 April 2014). Values are the means of 24 plants.

\begin{tabular}{|c|c|c|c|c|c|c|}
\hline \multirow{3}{*}{ Irrigation regime } & \multicolumn{3}{|c|}{ Haplopappus macrocephalus } & \multicolumn{3}{|c|}{ Selliera radicans } \\
\hline & Aerial & Root & Total & Aerial & Root & Total \\
\hline & \multicolumn{3}{|c|}{$-\mathrm{g}-$} & \multicolumn{3}{|c|}{$-\mathrm{g}-$} \\
\hline Twice per day [D2] & $6.6 \mathrm{a}$ & 4.1 & $10.7 \mathrm{a}$ & 4.4 & 0.8 & 5.2 \\
\hline Once per day [D1] & $6.4 \mathrm{a}$ & 4.2 & $10.6 \mathrm{a}$ & 3.4 & 0.7 & 4.1 \\
\hline Four times per week & $4.9 \mathrm{~b}$ & 2.9 & $7.8 \mathrm{~b}$ & 3.7 & 0.7 & 4.4 \\
\hline Significance $\dagger$ & $*$ & NS & $*$ & NS & NS & NS \\
\hline
\end{tabular}

$\dagger \mathrm{NS}$, *, not significant and significant at $\mathrm{P}<0.05$, respectively. Values followed by the same letter within a column are not statistically different.

\section{Literature Cited}

Benvenuti, S.; Bacci, D.

2010. Initial agronomic performances of Mediterranean xerophytes in simulated dry green roofs. Urban Ecosystems, 13: 349-363.

Durhman, A.K.; Rowe, D.B.; Rugh, C.L.

2007. Effect of substrate depth on initial growth, coverage, and survival of 25 succulent green roof plant taxa. HortScience, 42: 588-595.

Forschungsgesellschaft Landschaftsentwicklung Landschaftsbau (FLL).

2008. Guidelines for the planning, construction and maintenance of green roofing: Green roofing guideline. Bonn, Germany, 122 pp.

Getter, K.L.; Rowe, D.B.

2008. Selecting plants for extensive green roofs in the United States. Extension Bulletin E-3047. Michigan State University, 9 pp.

Getter, K.L.; Rowe, D.B.; Andresen, J.A.

2007. Quantifying the effect of slope on extensive green roof stormwater retention. Ecological engineering, 31: 225-231.

Getter, K.L.; Rowe, D.B.; Robertson, G.P.; Cregg, B.M.; Andresen, J.A.

2009. Carbon sequestration potential of extensive green roofs. Environmental Science and Technology, 43: 7564-7570.

Kokkinou, I.; Ntoulas, N.; Nektarios, P.A.; Varela, D.

2016. Response of native aromatic and medicinal plant species to water stress when grown on extensive green roof systems. HortScience. 51: 608-614.

Kosareo, L.; Ries, R.

2007. Comparative environmental life cycle assessment of green roofs. Building and environment 42: 2606-2613.

Kotsiris, G.; Androutsopoulos, A.; Polychroni, E.; Nektarios, P.A. 2012a. Dynamic $U$-value estimation and energy simulation for green roofs. Energy and Buildings, 45: 240-249.

Kotsiris, G.; Nektarios, P.A.; Paraskevopoulou, A.T.

2012b. Lavandula angustifolia growth and physiology is affected by substrate type and depth when grown under Mediterranean semi-intensive green roof conditions. HortScience, 47: 311-317.
Monterusso, M.A.; Rowe, B.D.; Rugh, C.L.

2005. Establishment and persistence of Sedum spp. and native taxa for green roof applications. Hortscience, 40, 391-396.

Nektarios, P.A.; Ntoulas, N.; Nydrioti, E.; Kokkinou, I.; Bali,

E.-M.; Amountzias, I.

2015. Drought stress response of Sedum sediforme grown in extensive green roof systems with different substrate types and depths. Scientia Horticulturae, 181: 52-61.

Nektarios, P.A.; Amountzias, I.; Kokkinou, I.; Ntoulas, N. 2011. Green roof substrate type and depth affect the growth of the native species Dianthus fruticosus under reduced irrigation regimens. HortScience, 46: 1208-1216.

Nektarios, P.A.; Ntoulas, N.; Kotopoulis, G.; Ttoulou, T.; Ilia, P. 2014. Festuca arundinacea drought tolerance and evapotranspiration when grown on two extensive green roof substrate depths and under two irrigation regimes. European Journal of Horticultural Science, 79: 142-149.

Ntoulas, N.; Nektarios, P.A.; Kapsali, T.-E.; Kaltsidi, M.-P.; Han, L.; Yin, S.

2015. Determination of the physical, chemical, and hydraulic characteristics of locally available materials for formulating extensive green roof substrates. Horttechnology, 25: 774-784.

Olate, E.; Gómez, M.F.; Musalem, M.; Sepúlveda, C.; Ferrer, J.M. 2013. Evaluation of native species for use in green roofs in the semiarid Mediterranean region of Central Chile. Acta Hort., 1000: 171-177.

Riedemann, P.; Aldunate, G.

2014. Native flora with ornamental value, identification and propagation. Chile, Central Zone. (In Spanish). Ediciones Jardín Botánico Chagual. Third Edition. Printed in Chile, $585 \mathrm{pp}$.

Santamouris, M.; Pavlou, C.; Doukas, P.; Mihalakakou, G.; Synnefa, A.; Hatzibiros, A.; Patargias, P.

2007. Investigating and analysing the energy and environmental performance of an experimental green roof system installed in a nursery school building in Athens, Greece. Energy, 32: 1781-1788. 
Snodgrass, E.C.; Snodgrass, L.L.

2006. Green roof plants: a resource and planting guide. Timber Press, Inc., Portland, Ore, 203 pp.

Takebayashi, H.; Moriyama, M.

2007. Surface heat budget on green roof and high reflection roof for mitigation of urban heat island. Building and Environment, 42, 2971-2979.
Van Renterghem, T.; Botteldooren, D.

2008. Numerical evaluation of sound propagating over green roofs. Journal of sound and vibration, 317: 781-799.

Yang, J.; Yu, Q.; Gong, P.

2008. Quantifying air pollution removal by green roofs in Chicago. Atmospheric environment, 42: 7266-7273. 
